\title{
Natural and anthropogenic changes in the insect fauna associated with carcasses in the North American Maritime lowlands
}

\author{
Jean-Philippe Michaud ${ }^{a}$, Christopher G. Majka ${ }^{b}$, Jean-Pierre Privéc ${ }^{c}$, Gaétan Moreau ${ }^{a, *}$ \\ a Département de biologie, Université de Moncton, Moncton, New Brunswick, E1A 3E9 Canada \\ ${ }^{\mathrm{b}}$ Nova Scotia Museum, 1747 Summer Street, Halifax, Nova Scotia, B3H 3A6 Canada \\ ${ }^{\mathrm{c}}$ Agriculture and Agri-Food Canada, 1045 Ryan Road, Bouctouche, New Brunswick, E4S 2J2 Canada
}

\section{A R T I C L E IN F O}

\section{Article history:}

Received 20 August 2009

Received in revised form 25 January 2010

Accepted 17 April 2010

Available online xxx

\section{Keywords:}

Carrion-related insects

Forensic entomology

Land cover change

Taxonomic composition

Time since colonisation

\begin{abstract}
A B S T R A C T
The insect pool available for carrion visitation and colonisation varies with geographical areas, hence the need to build a comprehensive database wherever such data could be used in forensic investigations. However, most of the geographic records on carrion-related insects are from short-term seasonal studies. Here, we provide the year-round taxonomic composition for the dominant ecosystem of the Maritime lowland ecological region that borders the Gulf of St. Lawrence, Canada, and we examine how this composition is subjected to natural (seasonal) as well as anthropogenic changes. Fresh pig carcasses, used here as human surrogates, were exposed recurrently throughout the whole annual period when carrion-related insects are active in forests and adjacent areas subjected to human-induced land cover changes from agricultural practices. A total of 130 necrophageous and predacious insect species representing 2 orders, 18 families and 75 genera were recovered from carcasses. Abundant fly species were able to visit and/or colonise carcasses exposed in both forests and agricultural fields but the species involved varied throughout the year. Conversely, the complex of abundant coleopterans found on carcasses remained stable throughout the year but differed between forests and agricultural fields. Considering the seasonal and anthropogenic changes that were observed in the complex of carrionrelated insects, we stressed that inference on the taxonomic composition in relation to minimum postmortem interval should be restricted to a specific habitat and time of the year. These results also have methodological implications, suggesting that the experimental designs of forensic studies in temperate areas require adjustments to permit robust estimations of minimum postmortem intervals from the insect fauna associated with carcasses.
\end{abstract}

(c) 2010 Elsevier Ireland Ltd. All rights reserved.

\section{Introduction}

Although considered patchy and ephemeral resources [1,2], animal carcasses are exploited by a rich complex of insects that, in combination with bacteria, are the driving factor structuring the decomposition process in the absence of vertebrate scavengers [3]. These insects are attracted in a successional manner by chemicals released during decomposition [4], and/or by other organisms visiting the carcass [5]. Since the mid 1970s, carrion-related insects have gained importance in criminal investigations because a number of studies have suggested that the minimum postmortem interval could be estimated either from the temperature-dependant developmental stages of fly larvae or from the relatively predictable succession pattern of the entire entomological complex [5,6]. However, because the insect pool available for colonisation and visitation of animal remains varies between

\footnotetext{
* Corresponding author. Tel.: +1 5068584975; fax: +1 5068584541.

E-mail address: gaetan.moreau@umoncton.ca (G. Moreau).
}

geographical areas, a carrion-related insect database is necessary for every geographical area where such data could be of use [7]. Moreover, due to insect seasonal cycles, this database might have to cover the different seasons of the geographical area to be of any use, especially in temperate ecosystems.

Simpson and Strongman [8] have commented on the fact that geographic records on carrion-related insects are scattered throughout the literature and most are only of limited use in a forensic investigation. In temperate eastern North America, for instance, a single year-round database of carrion-related insect fauna is available in the peer-reviewed literature [see [6]]. The term "yearround" refers to studies in which new carcasses are exposed recurrently throughout the whole annual period when carrionrelated insects are active. Here, we provide such a database for the Acadian forest, the principal ecosystem of the Maritime lowland ecological region, as well as for agricultural fields, the most abundant human-induced land cover change of this ecological region. The objectives of the study were (1) to document the insect complex that visits and colonises animal carcasses, (2) to identify general tendencies exhibited by the insect complex in relation to seasonal 
and anthropogenic influences, and (3) compare the complex to other published records of species occurrence. Since it is well known that the carrion insect community can differ in response to habitat characteristics [i.e., level of sun exposure; see [9]] and seasons [9,10], we expect that each land cover type, and possibly each season, will exhibit some level of uniqueness in regard to taxonomic composition.

\section{Material and methods}

\subsection{Study sites}

The study sites were located near Bouctouche $\left(46^{\circ} 26^{\prime} \mathrm{N}, 64^{\circ} 46^{\prime} \mathrm{W}\right)$, a rural area $50 \mathrm{~km}$ northeast of Moncton, New Brunswick, Canada, in the Maritime lowland ecological region [11]. The climate of the area is intermediate between a true Maritime and a true continental climate, with approximate temperatures of $3-10^{\circ} \mathrm{C}$ during the spring, $20-24{ }^{\circ} \mathrm{C}$ during the summer, and $6-10^{\circ} \mathrm{C}$ during the fall. The ecological region is covered mainly by the Acadian forest $(\approx 85 \%)$ and agricultural fields $(\approx 10 \%)$. Salt marshes and urban areas represent $<5 \%$ of the total surface. The Acadian forest is comprised of many species of trees and bushes (e.g., Betula spp., Populus spp., Picea spp., Alnus spp., Acer spp., Sorbus spp., Fagus grandifolia), whereas the agricultural fields are mostly comprised of medium-sized herbaceous plants, grasses and shrubs (e.g., Trifolium spp., Ranunculus spp., Prunella spp., Phleum spp., Plantago spp., Agrostis spp., Cornus canadensis, Amelanchier spp., Sambucus canadensis). Two blocks (A and B) were selected for the study. Each block included a forested area and an adjacent agricultural field. Block $A$ was located at the Agriculture and Agri-Food Canada research farm in Bouctouche, while block B was privately owned and located $2.2 \mathrm{~km}$ northwest of block A.

\subsection{Study subjects}

A 23-kg domestic pig (Sus scrofa) is currently considered as the best available animal model to mimic the decomposition of a human body [12]. Fresh pig carcasses, all weighing between $20 \mathrm{~kg}$ and $27 \mathrm{~kg}$, were obtained from a local certified hog farm. They were killed using a pin-gun. The open wound on the forehead of the animal potentially served as an additional colonisation point for some species (e.g., Calliphoridae). The carcasses were then immediately transported to the study sites in transparent garbage bags, and trials were underway within $2 \mathrm{~h}$ after death. A composite board consisting of a Styrofoam sheet $(1.22 \mathrm{~m} \times 0.61 \mathrm{~m}, 0.05 \mathrm{~m}$ in thickness) glued under a pressed-wood sheet $(1.22 \mathrm{~m} \times 0.61 \mathrm{~m}, 0.0063 \mathrm{~m}$ in thickness) and wrapped in a layer of polyurethane was placed directly on the ground at each exposure site. The composite board was then covered with approximately $5 \mathrm{~cm}$ of soilless potting mix (Canadian Growing Mix \#2, Fafard, Shippagan, N.B.), on top of which was placed the carcass. By isolating the carcasses from the ground and its organisms, the composite board allowed for homogeneous conditions between land cover types and also between exposure sites within the same land cover type. In addition, the board delimitated a sampling area for the collection of insects associated with the carcass. Otherwise, carrionrelated species that tend to burrow in the soil or hide in the vegetation would be difficult to recover. Each carcass was enclosed within a removable wooden frame $(1.22 \mathrm{~m} \times 0.61 \mathrm{~m} \times 0.61 \mathrm{~m})$ covered with chicken wire $(2.5 \mathrm{~cm}$ openings $)$ to prevent damage by vertebrate scavengers. The frame was secured to the ground with elastic cables anchored to $0.4 \mathrm{~m}$ plastic spikes. Two concrete blocks $(20 \mathrm{~kg} /$ block) were placed over the cage to further solidify the structure.

One carcass per land cover type was exposed on May 11th 2007 at site A; one carcass per land cover type was exposed on June 7th 2007 at site B; two carcasses were exposed in the field and one was exposed in the forest on June 27th 2007 at site $A$; two carcasses were exposed in the field and one was exposed in the forest on August 2nd 2007 at site B; one carcass per land cover type was exposed on September 5th 2007 at site A; one carcass per land cover type was exposed at site B on November 5th 2007; and finally one carcass per land cover type was exposed on May 6th 2008 at site A. On two dates, two carcasses were exposed because these replicates were needed to document decomposition in a concurrent study [31]. The composition of the fauna between replicates was very similar (see below). Carcasses were placed at least $50 \mathrm{~m}$ from each other or from prior exposure sites. To avoid potential edge effects [see [14,15]], carcasses were placed at a minimum distance of $20 \mathrm{~m}$ from the edge between forests and fields. In the field, carcasses were exposed to direct sunlight throughout the day. In the forest, it was not uncommon for sunlight to reach the carcasses at certain times during the day in the spring and fall. During the summer, the tree canopy generally sheltered the carcass from direct sunlight. After 26 days and 8 days, the carcasses exposed in the forest on May 11th 2007 and on June 7th 2007, respectively, were entirely removed from study sites by what we assumed to be a large vertebrate scavenger.

\subsection{Sampling and identification}

Carcasses were visited daily during the early stages of decomposition when the diversity of carrion insects is higher and when decomposition occurs more rapidly. The carcasses were visited every 2-3 days after the onset of the dry decay stage [7]. Prior to sampling the carcass, a visual assessment was made of the insect activity on the carcass with general notes on species abundance and behaviour. The cages were then removed carefully and manipulations were temporarily suspended so that the insects affected by cage removal (e.g., carrion flies) could return to their initial activities. Then, from a standing position, the abundance of every flying species was visually estimated. This was followed by the collection of a sample of flying insects with an entomology net ( $30 \mathrm{~cm}$ in diameter) for a maximum of $10 \mathrm{~min}$. Then, from a crouched position, a census of insects crawling or hiding under the carcass or in the ground was carried out. A collection of insects with forceps for a maximum of 10 min followed. To mitigate the potential effects of sampling on the insect community, a minimal number of specimens were collected for subsequent identification. Until formal identification, species that could not be identified visually in the field were given generic names. Diptera specimens were identified using McAlpine [16,17], Ozerov [18,19], and Whitworth [20]. Coleoptera specimens were identified using Anderson and Peck [21], Bousquet and Laplante [22], Campbell [23,24], Downie and Arnett [25], Klimaszewski [26], Peck and Cook [27], and Smetana [28-31]. Voucher specimens were deposited in the Université de Moncton insect collection. Only the insects in direct relationship with the carcass, thus the necrophageous and predacious insects, are presented below.

To determine whether adult carrion flies bred on carcasses, maggots were reared to adulthood. Based on results from a concurrent study [13], $<5 \%$ of the total volume of maggots was collected from all areas of the carcass at every collection date to maintain the integrity of the decomposition process. The maggot sample from each pig on each collection date was individually reared inside a 4-L plastic tub containing approximately $40 \mathrm{~g}$ of fresh beef liver as a food source and approximately $5 \mathrm{~cm}$ of a soilless pupation medium (Canadian Growing Mix \#2). The beef liver was placed into an aluminum or wet paper towel cup beforehand in a manner that would maximise the contact between the maggots and the food source [adapted from [32]]. The tubs were all covered with a layer of fine mesh screening and placed into a greenhouse at the research farm. During the summer, the greenhouse was neither heated nor cooled and the climate inside the greenhouse fluctuated with that of the natural environment. During the spring and fall, the greenhouse was maintained at $20-25{ }^{\circ} \mathrm{C}$ and $40-70 \%$ R.H. to maximise the rearing success. Once emerged, the adult flies were placed in plastic vials containing 70\% alcohol and subsequently identified using the methods described above.

\subsection{Statistical analyses}

The statistical analyses were performed using SAS version 9.0 [33]. Two presence-absence matrices, one for Diptera and one for Coleoptera, were generated using individual pig carcasses as rows and the most abundant insect species as columns. Abundant species are identified in Tables 1 and 2. Although rare species can yield information about habitat preference, they were excluded from the statistical analyses because (1) their rarity would render the analysis sensitive to erratic occurrences, and (2) rare species were often confined to a single carcass. A correspondence analysis was performed on each matrix to examine the association between individual carcasses and the insect species, and thus reveal broad seasonal and anthropogenic changes in taxonomic composition. Many Diptera species qualified for the analysis but correspondence analysis is restrictive in the sense that the number of columns is limited by the number of rows. Thus, to obtain a general representation of the insect complex that gives emphasis to species with established forensic potential, the most abundant calliphorids and at least one species per Diptera family with abundant species was included in the analysis. For Coleoptera, we pooled the presence-absence data for the 4 species of the family Leodidae ( 4 species), as well as for the 8 species of the family Histeridae because identification beyond the family level is not possible in the field but species within each family have similar life histories. The two carcasses removed by scavengers were not included in correspondence analyses.

To validate the analyses discussed above, other tests (not shown) were applied to the presence-absence matrices. First, correspondence analyses conducted with respect to field sites $A$ and $B$ did not discriminate between sites, thus indicating that occurrences of abundant insect species were relatively similar in both study areas. Second, correspondence analyses conducted with respect to field temperature did not discriminate between carcasses exposed in cool (i.e., spring and fall) and warm temperatures (i.e., summer), indicating that seasonality (see below) is not solely attributable to changes in temperature. When replication was present, replicates were typically located proximately on the figures, indicating that occurrences of abundant insect species did not differ between replicates.

\section{Results}

A total of 130 necrophageous and predacious insect species representing 2 orders, 18 families and 75 genera were collected throughout the study (Tables 1 and 2 ).

\subsection{Diptera}

The Diptera were represented by 7 families and 34 species but heteromyzids, sarcophagids, and some muscids were not identi- 
Table 1

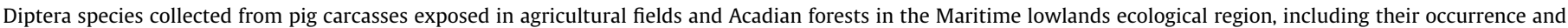
distribution.

\begin{tabular}{|c|c|c|c|c|c|c|}
\hline \multirow[t]{2}{*}{ Order } & \multirow[t]{2}{*}{ Family } & \multirow[t]{2}{*}{ Species } & \multicolumn{2}{|c|}{ Land cover type ${ }^{a}$} & \multirow[t]{2}{*}{ Occurrence $^{b}$} & \multirow[t]{2}{*}{ Distribution } \\
\hline & & & Field & Forest & & \\
\hline \multirow[t]{34}{*}{ Diptera } & \multirow[t]{11}{*}{ Calliphoridae } & Calliphora vomitoria (Linnaeus) ${ }^{\mathrm{d}}$ & A, I & A, I & Abundant & Widespread \\
\hline & & Calliphora livida (Hall) ${ }^{\mathrm{d}}$ & A, I & A, I & Abundant & Widespread \\
\hline & & Calliphora terraenovae (Macquart) & A & A & Rare & Widespread \\
\hline & & Calliphora vicina (Robineau-Desvoidy) & - & I & Rare & Widespread \\
\hline & & Cochlyomia macellaria (Fabricius) & A & - & Rare & Nearctic \\
\hline & & Cynomya cadaverina (Robineau-Desvoidy) & A, I & A, I & Abundant & Nearctic \\
\hline & & Lucilia illustris (Meigen) ${ }^{\mathrm{d}}$ & A, I & A, I & Abundant & Widespread \\
\hline & & Lucilia sericata (Meigen) & A & - & Abundant & Widespread \\
\hline & & Phormia regina (Meigen) ${ }^{\mathrm{d}}$ & A, I & A, I & Abundant & Widespread \\
\hline & & Pollenia spp. & A & A & Common & Widespread \\
\hline & & Protophormia terraenovae (Robineau-Desvoidy) ${ }^{\mathrm{d}}$ & A, I & A, I & Abundant & Widespread \\
\hline & Heleomyzidae & Not identified beyond family level & A & A & Abundant & - \\
\hline & \multirow[t]{5}{*}{ Muscidae } & Eudasyphora spp. & A & A & Abundant & Widespread \\
\hline & & Musca spp. ${ }^{\mathrm{d}}$ & A & A & Abundant & Widespread \\
\hline & & Ophyra spp. 1 & A & A & Abundant & Widespread \\
\hline & & Ophyra spp. 2 & A & A & Abundant & Widespread \\
\hline & & Unknown & A & A & Abundant & - \\
\hline & \multirow[t]{6}{*}{ Piophilidae } & Liopiophila varipes (Meigen) & A & A & Abundant & Holarctic \\
\hline & & Parapiophila spp. & A & A & Abundant & - \\
\hline & & Prochyliza spp. & A & A & Common & - \\
\hline & & Protopiophila latipes (Meigen) & A & A & Abundant & Holarctic \\
\hline & & Stearibia nigriceps (Meigen) $)^{\mathrm{d}}$ & A & A & Abundant & Holarctic \\
\hline & & Unknown & A & A & Abundant & - \\
\hline & Sarcophagidae & Not identified beyond family level & A & A & Abundant & - \\
\hline & \multirow[t]{7}{*}{ Sepsidae } & Enicita annulipes (Meigen) & A & - & Rare & Holarctic \\
\hline & & Enicomira minor (Haliday) & A & - & Rare & Holarctic \\
\hline & & Meroplius stercorarius (Wiedemann) & A & A & Abundant & Holarctic \\
\hline & & Nemopoda nitidula (Fallen) & A & A & Abundant & Holarctic \\
\hline & & Sepsis neocynipsea (Melander \& Spuler) & A & - & Abundant & Holarctic \\
\hline & & Sepsis punctum (Fabricius) & A & - & Rare & Holarctic \\
\hline & & Themira nigricornis (Meigen) ${ }^{\mathrm{d}}$ & A & A & Abundant & Holarctic \\
\hline & \multirow[t]{3}{*}{ Sphaerocidae } & Ishiolepta spp. & A & A & Common & Widespread \\
\hline & & Lotophila atra (Meigen) ${ }^{\mathrm{d}}$ & A & A & Abundant & Widespread \\
\hline & & Sphaerocera spp. ${ }^{\mathrm{d}}$ & A & A & Abundant & Widespread \\
\hline
\end{tabular}

a " $A$ " denotes species collected in the adult stage and "I" denotes species collected as immatures.

b The terms "Rare", "Common", and "Abundant" denote species that were recovered <4 times, between 5 and 9 times, and more than 10 times, respectively.

c The terms "Widespread" indicate that the species is distributed in more than one biogeographic realm.

d Species or genus included in the correspondence analysis.

fied beyond the family level (Table 1 ). All of the Diptera species collected either had a widespread or Holarctic distribution (Table 1). The rearing of fly larvae to adulthood showed that all but one of the abundant calliphorid species actively bred on carcasses (Table 1 ). The first plane of a correspondence analysis for abundant dipterans explained most of the variability ( $74 \%$ of total inertia) in the association between individual carcasses and Diptera species (Fig. 1). With the exception of the carcass exposed in the forest on June 27th 2007, the analysis separated the individual carcasses in three seasonal groups: spring, summer, and fall. From the matrix of the correspondence analysis, we determined that differentiation on the horizontal axis was mainly due to spring affinity in T. nigriceps, $L$. atra, and $C$. livida, as well as summer and fall affinity in L. illustris. Differentiation on the vertical axis was mainly due to Musca spp., C. vomitoria, and C. livida. The analysis did not identify any shift in taxonomic composition of Diptera with respect to the land cover type (i.e., agricultural fields or forested sites).

\subsection{Coleoptera}

The Coleoptera were represented by 11 families and 96 species, with $38 \%$ of the species being considered as adventive Palaearctic

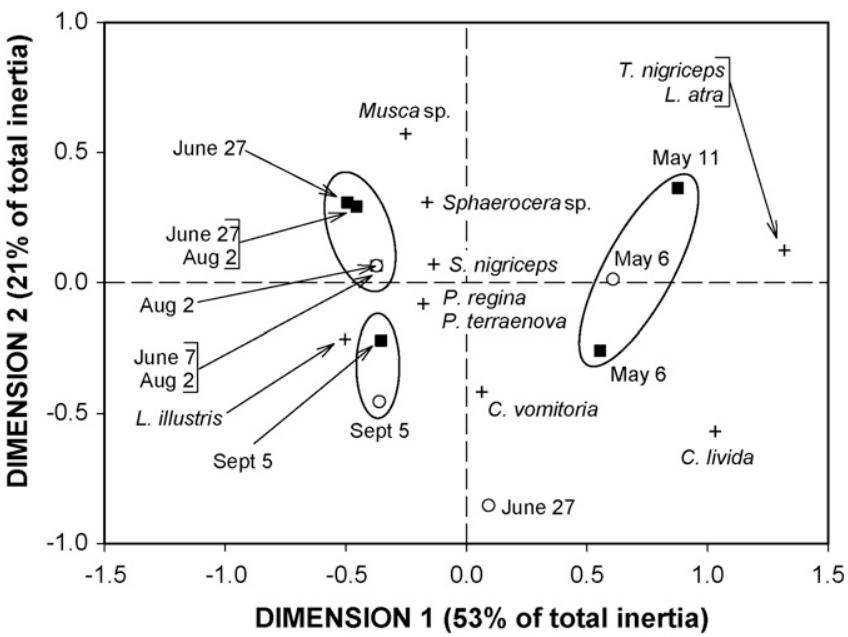

Fig. 1. Plot for the two first dimensions of the correspondence analysis for abundant dipterans. Black squares and open circles represent individual carcasses labelled according to the first day of exposure in the field and in the forest, respectively. Crosses represent individual species. Ellipses regroup the individual carcasses according to the seasons. 
Table 2

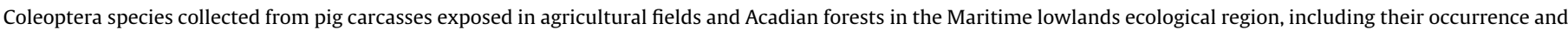
origin.

\begin{tabular}{|c|c|c|c|c|c|c|}
\hline \multirow[t]{2}{*}{ Order } & \multirow[t]{2}{*}{ Family } & \multirow[t]{2}{*}{ Species } & \multicolumn{2}{|c|}{ Land cover type ${ }^{a}$} & \multirow[t]{2}{*}{ Occurrence $^{b}$} & \multirow[t]{2}{*}{ Origin $^{c}$} \\
\hline & & & Field & Forest & & \\
\hline \multirow[t]{68}{*}{ Coleoptera } & Cleridae & Necrobia violacea (Linnaeus) ${ }^{\mathrm{d}}$ & A & A & Abundant & Adventive \\
\hline & & Necrobia rufipes (DeGeer) & A & - & Rare & Adventive \\
\hline & Dermestidae & Dermestes talpinus (Mannerheim) & A & - & Abundant & Native \\
\hline & Geotrupidae & Geotrupes balyi (Jekel) & - & A & Rare & Native \\
\hline & & Geotrupes stercorarius (Linnaeus) & A & - & Rare & Adventive \\
\hline & Histeridae $^{d}$ & Carcinops pumilo (Erichson) & A & - & Rare & Adventive \\
\hline & & Euspilotus assimilis (Paykul) & A & - & Abundant & Native \\
\hline & & Hister abbreviatus (Fabricius) & A & - & Abundant & Native \\
\hline & & Hister furtivus (LeConte) & A & A & Abundant & Native \\
\hline & & Margarinotus brunneus (Fabricius) & A & - & Common & Adventive \\
\hline & & Margarinotus faedatus (LeConte) & A & A & Common & Native \\
\hline & & Margarinotus hudsonicus (Casey) & A & A & Abundant & Native \\
\hline & & Margarinotus lecontei (Wenzel) & - & A & Rare & Native \\
\hline & Hydrophilidae & Cercyon haemorrhoidalis (Fabricius) & A & A & Common & Adventive \\
\hline & & Cercyon minusculus (Melsheimer) & - & A & Common & Native \\
\hline & & Cryptopleurum minutum (Fabricius) & A & - & Common & Adventive \\
\hline & & Sphaeridium bipustulatum (Fabricius) & A & - & Common & Adventive \\
\hline & & Sphaeridium lunatum (Fabricius) & A & A & Common & Adventive \\
\hline & & Sphaeridium scarabaeoides (Linnaeus) & A & - & Rare & Adventive \\
\hline & Leodidae $^{\mathrm{d}}$ & Catops basilaris (Say) & - & A & Abundant & Native \\
\hline & & Catops simplex (Say) & - & A & Abundant & Native \\
\hline & & Prionochaeta opaca (Say) & - & A & Common & Native \\
\hline & & Sciodrepoides terminans (LeConte) & - & A & Abundant & Native \\
\hline & Nitidulidae & Glischrochilus quadrisignatus (Say) & A & - & Rare & Native \\
\hline & & Glischrochilus siepmanni (Brown) & - & A & Common & Native \\
\hline & & Nitidula bipuncata (Linnaeus) & A & - & Rare & Adventive \\
\hline & & Nitidula rufipes (Linnaeus) & A & - & Common & Adventive \\
\hline & & Omosita $^{\mathrm{d}}$ colon (Linnaeus) & A & A & Abundant & Adventive \\
\hline & & Omosita discoidea (Fabricius) & - & A & Rare & Adventive \\
\hline & Scarabeidae & Agoliinus guttatus (Eschscholtz) & A & - & Common & Native \\
\hline & & Aphodius fimentarius (Linnaeus) & A & - & Rare & Adventive \\
\hline & & Calamosternus granarius (Linnaeus) & A & - & Common & Adventive \\
\hline & & Chilothorax distinctus (Müller) & A & - & Rare & Adventive \\
\hline & & Colobopterus erraticus (Linnaeus) & A & - & Rare & Adventive \\
\hline & & Eupleurus subterraneus (Linnaeus) & A & - & Rare & Adventive \\
\hline & & Melinopterus prodromus (Brahm) & A & A & Abundant & Adventive \\
\hline & & Onthophagus $h$. hecate (Panzer) & A & A & Rare & Native \\
\hline & & Onthophagus nuchicornis (Linnaeus) & A & - & Abundant & Native \\
\hline & Silphidae & Necrodes surinamensis (Fabricius) ${ }^{\mathrm{d}}$ & A & A & Abundant & Native \\
\hline & & Necrophila americana (Linnaeus) ${ }^{\mathrm{d}}$ & A & A & Abundant & Native \\
\hline & & Nicrophorus ${ }^{\mathrm{d}}$ defodiens (Mannerheim) & - & A & Abundant & Native \\
\hline & & Nicrophorus investigator (Zetterstedt) & - & A & Rare & Native \\
\hline & & Nicrophorus orbicollis (Say) & - & A & Rare & Native \\
\hline & & Nicrophorus pustulatus (Herschel) & - & A & Rare & Native \\
\hline & & Nicrophorus tomentosus (Weber) & A & A & Rare & Native \\
\hline & & Nicrophorus sayi (Laporte) & - & A & Common & Native \\
\hline & & Oiceptoma novaboracense (Forster) ${ }^{\mathrm{d}}$ & A & A & Abundant & Native \\
\hline & & Thanatophilus lapponicus (Herbst) & A & - & Rare & Native \\
\hline & Staphylinidae & Aleochara bimaculata (Gravenhorst) & A & - & Rare & Native \\
\hline & & Aleochara curtula (Goeze) & A & A & Abundant & Adventive \\
\hline & & Aleochara fumata (Gravenhorst) & - & A & Rare & Adventive \\
\hline & & Aleochara sculptiventris (Casey) & A & - & Common & Native \\
\hline & & Aleochara sekanai (Klimaszewski) & A & - & Rare & Native \\
\hline & & Aleochara verna (Say) & A & - & Abundant & Native \\
\hline & & Acrolocha diffusa (Fauvel) & - & A & Rare & Native \\
\hline & & Atheta $n r$. smetanai \& campbelli (Lohse) & A & - & Rare & Native \\
\hline & & Atheta districta (Casey) & - & A & Rare & Native \\
\hline & & Atheta longicornis (Gravenhorst) & - & A & Rare & Adventive \\
\hline & & Atheta pseudcrenuliventris (Klimaszewski) & - & A & Rare & Native \\
\hline & & Atheta savardae (Klimaszewski \& Majka) & - & A & Rare & Native \\
\hline & & Atheta spp. & & & & \\
\hline & & Bisnius blandus (Gravenhorst) & - & A & Rare & Native \\
\hline & & Creophilus maxillosus villosus (Gravenhorst) ${ }^{\mathrm{d}}$ & A & A & Abundant & Native \\
\hline & & Dinothenarus capitatus (Bland) & - & A & Rare & Native \\
\hline & & Gabrius microphthalamus (Horn) & - & A & Common & Native \\
\hline & & Gennadota canadensis (Casey) & - & A & Rare & Native \\
\hline & & Gyrohypnus fracticornis (Müller) & A & A & Rare & Adventive \\
\hline & & Lathrobium confusum (Leconte) & - & A & Rare & Native \\
\hline
\end{tabular}


Table 2 (Continued)

\begin{tabular}{|c|c|c|c|c|c|c|}
\hline \multirow[t]{2}{*}{ Order } & \multirow[t]{2}{*}{ Family } & \multirow[t]{2}{*}{ Species } & \multicolumn{2}{|c|}{ Land cover type ${ }^{\mathrm{a}}$} & \multirow[t]{2}{*}{ Occurrence $^{\mathrm{b}}$} & \multirow[t]{2}{*}{ Origin $^{c}$} \\
\hline & & & Field & Forest & & \\
\hline & & Mocyta fungi (Gravenhorst) & A & - & Rare & Adventive \\
\hline & & Nehemitropia lividipennis (Mannerheim) & A & - & Rare & Adventive \\
\hline & & Neohypnus obscurus (Erichson) & A & - & Rare & Native \\
\hline & & Ontholestes cingulatus (Gravenhorst) ${ }^{\mathrm{d}}$ & A & A & Abundant & Native \\
\hline & & Philhygra spp. & & & & \\
\hline & & Philonthus caeruleipennis (Mannerheim) & - & A & Rare & Native \\
\hline & & Philonthus carbonarius (Gravenhorst) & A & A & Common & Adventive \\
\hline & & Philonthus cruentatus (Gmelin) & A & - & Abundant & Adventive \\
\hline & & Philonthus hepaticus (Erichson) & A & - & Rare & Native \\
\hline & & Philonthus politus (Linnaeus) & A & A & Abundant & Adventive \\
\hline & & Philonthus rectangulus (Sharp) & A & A & Abundant & Adventive \\
\hline & & Philonthus sericans (Gravenhorst) & - & A & Rare & Native \\
\hline & & Philonthus sericinus (Horn) & A & - & Rare & Native \\
\hline & & Philonthus varians (Paykull) & A & A & Abundant & Adventive \\
\hline & & Platystethus americanus (Erichson) & - & A & Rare & Native \\
\hline & & Quedius cinctus (Paykull) & A & - & Rare & Adventive \\
\hline & & Quedius erythrogaster (Mannerheim) & - & A & Rare & Native \\
\hline & & Quedius mesomelinus (Marsham) & - & A & Rare & Adventive \\
\hline & & Quedius rusticus (Smetana) & - & A & Rare & Native \\
\hline & & Tachinus fumipennis (Say) & - & A & Common & Native \\
\hline & & Tachinus luridus (Erichson) & A & A & Abundant & Native \\
\hline & & Tachinus memnonius (Gravenhorst) & - & A & Rare & Native \\
\hline & & Tachinus quebecensis (Roberts) & - & A & Common & Native \\
\hline & & Tachyporus dispar (Paykull) & - & A & Rare & Adventive \\
\hline & & Tachyporus mexicanus (Sharp) & A & - & Rare & Native \\
\hline & & Xantholinus linearis (Olivier) & A & - & Rare & Adventive \\
\hline & \multirow[t]{2}{*}{ Trogidae } & Trox unistriatus (Beauvois) & A & A & Abundant & Native \\
\hline & & Trox variolatus (Melsheimer) & - & A & Rare & Native \\
\hline
\end{tabular}

a " $A$ " denotes species collected in the adult stage.

b The terms "Rare", "Common", and "Abundant" denote species that were recovered < 4 times, between 5 and 9 times, and more than 10 times, respectively.

c The term "Adventive" is used to indicate species living outside their native distributional ranges.

d Species, genus, or family included in the correspondence analysis.

species (Table 2). Eight staphylinids (Aleochara bimaculata, Aleochara sekanai, Lathrobium confusum, Philonthus hepaticus, Philonthus sericinus, Platystethus americanus, Quedius cinctus, Quedius erythrogaster), two scarabids (Agoliinus guttatus, Chilothorax distinctus), and one clerid (Necrobia rufipes) were recorded for the first time in New Brunswick. No efforts were made to identify the Coleoptera larvae. The first plane of a correspondence analysis for abundant coleopterans explained most of the

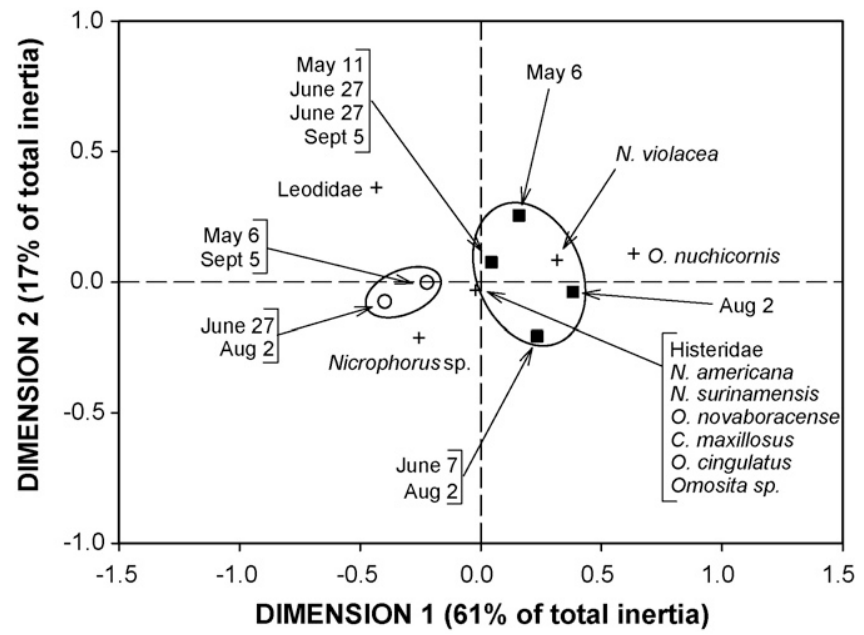

Fig. 2. Plot of the two first dimensions of the correspondence analysis for abundant coleopterans. Black squares and open circles represent individual carcasses labelled according to the first day of exposure in the field and in the forest, respectively. Crosses represent individual species. Ellipses regroup the individual carcasses according to the land cover type. variability ( $78 \%$ of total inertia) in the association between individual carcasses and abundant species (Fig. 2). This time, the analysis separated the individual carcasses according to the land cover type, but not according to seasons (Fig. 2). From the matrix of the correspondence analysis, we identified that differentiation in two groups on the horizontal axis was due to 0 . nuchicornis absence from forested sites and consistent presence in agricultural fields, as well as to the ubiquity of species of the family Leodidae in forested sites and their inconsistent presence in agricultural fields. The species found close to the centre of the plane were omnipresent in all seasons and land cover types.

\section{Discussion}

This study presents the first year-round assessment of necrophageous and predacious insect taxa capable of visiting and/or colonising carrion in the Maritime lowland ecological region. To the best of our knowledge, this is only the second yearround database available in the peer-reviewed literature for the eastern temperate forests, a vast area that encompasses 31 American states, entirely or in part, and parts of four Canadian provinces [11]. This species list not only allows for a better understanding of the taxonomic composition of the carrion insect fauna of the northern part of this region, it also reveals shifts in composition due to seasonal conditions and human-induced ecosystem disturbances.

\subsection{Diptera}

In this study, the taxonomic composition of the most abundant Diptera species was influenced by seasonal effects but every abundant species was able to visit and/or breed on carcasses 
exposed in both land cover types. Although some studies have suggested that certain fly species are only found in shady (i.e., woody) or sunny habitats, others have found that fly species could colonise in both sunny and shaded conditions, which may indicate that habitat preference varies according to the geographic region [see [9]]. With the exception of taxa recovered in all seasons (i.e., $P$. regina, $P$. terraenova, $S$. nigriceps), the occurrence of fly species was subject to seasonal effects, as expected from the literature [see [9]]. These seasonal shifts in species that tend to colonise early in the succession on carrion highlight the need for year-round studies of colonisation ability of flies before accurate estimations of the time since colonisation can be made from developmental stages. A single carcass, the one exposed in the forest on June 27th 2007, did not conform to seasonal assemblages. This can be explained, in part, by the spring-like temperatures observed in the forest in lateJune, especially at night. Conversely, carcasses in the field in the same period were exposed to typical summer temperatures. This isolated event illustrates the importance of considering proximal temperatures in addition to seasonal effects for the study of fly visitation and/or colonisation pattern.

Records from forensic studies conducted in Nova Scotia [8,34], $<200 \mathrm{~km}$ away from our sites, show a similar taxonomic composition in regard to calliphorid species of forensic importance, with all but one species collected there not being recovered at our study sites. Six of our eleven calliphorid species were collected on pig carcasses in Virginia [6], $<2000 \mathrm{~km}$ to the south-west. Conversely, most of our Diptera species from other families were not part of the insect fauna documented on carcasses in Virginia. Only four of our 34 Diptera species were recovered from pig carcasses in south-western British Columbia [7], $<4000 \mathrm{~km}$ to the west.

\subsection{Coleoptera}

A different picture emerges from the study of the taxonomic composition of abundant Coleoptera. Overall, most species had the capacity to visit the carcasses exposed in both land cover types but the occurrence of $O$. nuchicornis and species of the family Leodidae differed between habitats. These changes may be due to changes in landscape permeability and connectivity due to afforestation [35], or to changes in population dynamics and trophic interactions in the altered habitat $[36,37]$. Habitat-specific occurrence has been used in the past by forensic entomologists to infer that a body had been moved from the initial location where it rested [38]. Because Coleoptera are sensitive to cold temperatures in a similar way to Diptera, the absence of seasonal effect on the taxonomic composition of abundant Coleoptera is somewhat surprising and may indicate that burrowing insects are less sensitive to annual shifts in temperature than flying insects. Nevertheless, the absence of effects on taxonomic composition does not imply that there is no difference in colonisation of carcasses, departure from carcasses, or species abundance.

Our species list contributes significantly to both the forensic and general taxonomy literature. Most of the Coleoptera species collected on pig carcasses in Nova Scotia (i.e., 9 out of $9[8,34]$ ), Southwest Virginia (i.e., 18 out of 22 [6]) or British Columbia (i.e., 13 out of 18 [7]) were also recovered in our study. Conversely, most of the necrophageous and predacious Coleoptera species that we collected have never been reported in the forensic literature. Eleven Coleoptera species never previously recorded in New Brunswick were collected at the study sites. Eight of these species [N. rufipes (Cleridae), A. guttatus (Scarabaeidae), C. distinctus (Scarabaeidae), A. bimaculata (Staphylinidae), L. confusum (Staphylinidae), P. sericinus (Staphylinidae), P. americanus (Staphylinidae), and $Q$. erythrogaster (Staphylinidae)] most likely reflect insufficient collecting effort in New Brunswick since they are all recorded in Quebec and Nova Scotia, the two adjacent provinces.
However, new records for three staphilinids illustrate considerable species range extensions. Aleochara sekanai (Staphylinidae) was only previously known from northern regions from Alaska to northern Ontario [39]; the only Canadian record of $P$. hepaticus (Staphylinidae) was a specimen collected in Vancouver, British Columbia, a species otherwise known from southern Mexico north to central Massachusetts [40]; finally, our record of $Q$. cinctus (Staphylinidae) represents the first official Canadian record for the species [41]. The former two species illustrate how areas in temperate regions such as New Brunswick can be zoogeographic transition zones where species that have arctic and neotropical distributions can be found together at the extremes of their respective ranges.

Interestingly, $38 \%$ of the 96 beetle species collected in this study were adventive taxa, a value three times larger than the average percentage for the beetle fauna of New Brunswick(12.7\%, C.G. Majka, unpublished data), an indication of the importance of this suite of beetles and the degree to which adventive species have colonised decompositional environments such as carrion. This agrees well with a study of the carrion and dung fauna from Boreal (Aegolius funereus richardsoni) and Northern Saw-whet Owl nests (Aegolius acadicus acadicus) in Nova Scotia, which found that $50 \%$ of the beetles inhabiting this decompositional environment were adventive Palaearctic species [42]. This, along with the records of range extension and current climatic context, suggests that the taxonomic composition of carrion fauna is constantly shifting, and that carrionrelated insect databases should be updated frequently.

\subsection{General considerations}

A thorough determination of the taxonomic composition of the geographical area under study has permitted us to identify the year-round complex of carrion-related insects, which lays the groundwork for future studies on carrion insect succession in the northern part of the eastern temperate forests. Published records of species occurrence are also useful to detect shifts in species range, thus permitting a recalibration of our methodological approach when using insect fauna to estimate the minimum postmortem interval.

In contrast to the contemporary approach, we did not study the insect complex according to the level of sun/shade as we expected greater differences in community structure between than within habitat types. Seasonal and anthropogenic changes in the complex provide support for the viewpoint that inference on the taxonomic composition of the carrion insect complex in relation to timesince-death should be restricted to a specific habitat and time of the year, especially in temperate areas. Considering the variability associated with temperatures within each season, significant insight may be gained if further studies of insect fauna associated with carcasses would consider a sequential exposure of fresh carcasses throughout the year (i.e., decomposition trials initiated at regular intervals during the entire year) instead of a simultaneous exposure of several carcasses in a single season.

\section{Acknowledgements}

The authors thank A. Leblanc and the staff at the Agriculture and Agri-Food Canada research farm in Bouctouche for their valuable help; Tony for his excellent service in providing us with study subjects; the Nova Scotia Museum for providing us with access to the insect collection; R. Meier, from the National University of Singapore, and J. Savage, from Bishop's University for the verification of Sepsidae and Muscidae identifications, respectively; J. Klimaszewski of the Canadian Forest Service for Aleocharine identifications; two anonymous reviewers for comments on a previous version of this manuscript; and finally J. Phillips, C. 
Comeau, J. Goguen, and A. MacKay for their help with lab and field work. This study was supported by NSERC Discovery, FESR, and NBIF grants.

\section{References}

[1] K.A. Kneidel, Patchiness aggregation and the coexistence of competitors for ephemeral resources, Ecol. Entomol. 10 (1985) 441-448.

[2] K. Schoenly, W. Reid, Dynamics of heterotrophic succession in carrion arthropod assemblages: discrete series or a continuum of change? Oecologia 73 (1987) 192 202

[3] M. Coe, The decomposition of elephant carcasses in the Tsavo (East) National Park, Kenya, J. Arid. Environ. Res. 1 (1978) 71-86.

[4] C.P. Campobasso, G. Di Vella, F. Introna, Factors affecting decomposition and Diptera colonization, Forensic Sci. Int. 120 (2001) 18-27.

[5] M.L. Goff, Estimation of postmortem interval using arthropod development and successional patterns, Forensic Sci. Rev. 5 (1993) 81-94.

[6] K. Tabor, R. Fell, C. Brewster, Insect fauna visiting carrion in Southwest Virginia, Forensic Sci. Int. 150 (2005) 73-80.

[7] G.S. Anderson, S.L. VanLaerhoven, Initial studies on insect succession on carrion in south western British Columbia, J. Forensic Sci. 41 (1996) 617-625.

[8] G. Simpson, D.B. Strongman, Carrion insects on pig carcasses at a rural and an urban site in Nova Scotia, Can. Soc. Forensic Sci. J. 35 (2002) 123-143.

[9] G.S. Anderson, Insect succession on carrion and its relationship to determining the time of death, in: J.H. Byrd, J.L. Castner (Eds.), Forensic Entomology: The Utility of Arthropods in Legal Investigations, CRC Press, Boca Raton, Florida, 2001, pp. 143175.

[10] J.-P. Michaud, G. Moreau, Predicting the visitation of carcasses by carrion-related insects under different rates of degree-day accumulation, Forensic Sci. Int. 185 (2009) 78-83.

[11] Commission for Environmental Cooperation (CEC), Ecological Regions of North America: Towards a Common Perspective, CEC Press, Montreal, Canada, 1997.

[12] K.G. Schoenly, N.H. Haskell, R.D. Hall, J.R. Gbur, Comparative performance an complementarity of four sampling methods and arthropod preference tests from human and porcine remains at the Forensic Anthropology Center in Knoxville Tennessee, J. Med. Entomol. 44 (2007) 881-894.

[13] J. Phillips, J.-P. Michaud, G. Moreau, Carcass decay through feeding activities of larval flies does not facilitate subsequent colonization by beetles, in: Proceedings of the North American Forensic Entomology Association, 7th Annual Meeting, Miami, Florida, July 16-17, (2009), p. 35.

[14] R.L. Smith, T.M. Smith, Ecology and Field Biology, Benjamin Cumming, New York, New York, US, 2002

[15] A. Fielder, M. Halbach, B. Sinclair, M. Benecke, What is the edge of a forest? A diversity analysis of adult Diptera found on decomposing piglets inside and on the edge of a Western German woodland inspired by a courtroom question, Entomologie Heute 20 (2008) 173-191.

[16] J.F. McAlpine (Ed.), Manual of Nearctic Diptera, vol. 1, Biosystematics Research Institute, Ottawa, Ontario, Monograph No. 27, 1981

[17] J.F. McAlpine (Ed.), Manual of Nearctic Diptera, vol. 2, Biosystematics Research Institute, Ottawa, Ontario, Monograph No. 28, 1987.

[18] A.L. Ozerov, A review of the genus Themira Robineau-Desvoidy, 1830 (Diptera: Sepsidae) of the World, with a revision of the North American species, Russian Entomol. J. 7 (1999) 169-208.

[19] A.L. Ozerov, Revision of the Nearctic species of the genus Sepsis Fallen, 1810 (Diptera: Sepsidae), Russian Entomol. J. 9 (2000) 161-176.

[20] T. Whitworth, Keys to the genera and species of blow flies (Diptera: Calliphoridae) of America north of Mexico, Proc. Entomol. Soc. Wash. 108 (2006) 689-725.
[21] R.S. Anderson, S.B. Peck, The Carrion Beetles of Canada and Alaska (Coleoptera: Silphidae and Agyrtidae), The Insects and Arachnids of Canada, Part 13, Agriculture Canada Publication 1778, Ottawa, Canada, 1985.

[22] Y. Bousquet, S. Laplante, Coleoptera Histeridae: The Insects and Arachnids of Canada, Part 24, NRC Research Press, Ottawa, Ontario, 2006.

[23] J.M. Campbell, A revision of the genus Tachinus (Coleoptera: Staphylinidae) of North and Central America, Mem. Entomol. Soc. Can. 90 (1973) 1-137.

[24] J.M. Campbell, A revision of the genus Tachyporus Gravenhorst (Coleoptera: Staphylinidae) of North and Central America, Mem. Entomol. Soc. Can. 109 (1979) 1-95.

[25] N.M. Downie, R.H. Arnett Jr., The Beetles of Northeastern North America, Sandhill Crane Press, Gainesville, Florida, 1996.

[26] J. Klimaszewski, A revision of the genus Aleochara Gravenhorst of America north of Mexico (Coleoptera: Staphylinidae, Aleocharinae), Mem. Entomol. Soc. Can. 129 (1973) 1-211.

[27] S.B. Peck, J. Cook, Systematics, distributions, and bionomics of the small carrion beetles (Coleoptera: Leiodidae: Cholevinae: Cholevini) of North America, Can. Entomol. 134 (2002) 723-787.

[28] A. Smetana, Revision of the tribe Quediini of America north of Mexico (Coleoptera: Staphylinidae), Mem. Entomol. Soc. Can. 79 (1971) 1-303.

[29] A. Smetana, Revision of the subfamily Xantholininae of America north of Mexico (Coleoptera: Staphylinidae), Mem. Entomol. Soc. Can. 120 (1982) 1-389.

[30] A. Smetana, Review of the family Hydrophilidae of Canada and Alaska (Coleoptera), Mem. Entomol. Soc. Can. 142 (1988) 1-316.

[31] A. Smetana, Rove beetles of the subtribe Philonthina of America north of Mexico (Coleoptera: Staphylinidae) classification, phylogeny and taxonomic revision, Mem. Entomol. Int. 3 (1995) 1-946.

[32] N.H. Haskell, W.D. Lord, J.H. Byrd, Collection of entomological evidence during death investigations, in: J.H. Byrd, J.L. Castner (Eds.), Forensic Entomology: The Utility of Arthropods in Legal Investigations, CRC Press, Boca Raton, Florida, 2001 pp. 81-120.

[33] SAS Institute, SAS User's Guide: Statistics, Statistical Analysis System Institute, Cary, NC, 1999.

[34] H.N. Leblanc, D.B. Strongman, Carrion insects associated with small pig carcasses during fall in Nova Scotia, Can. Soc. Forensic Sci. J. 35 (2002) 145-152.

[35] I. Hanski, Habitat connectivity, habitat continuity, and metapopulations in dynamic landscapes, Oikos 87 (1999) 209-219.

[36] G. Moreau, E.S. Eveleigh, C.J. Lucarotti, D.T. Quiring, Ecosystem alteration modifies the relative strengths of bottom-up and top-down forces in a herbivore population, J. Anim. Ecol. 75 (2006) 853-861.

[37] G. Moreau, E.S. Eveleigh, C.J. Lucarotti, D.T. Quiring, Stage-specific responses to ecosystem alteration in an eruptive herbivorous insect, J. Appl. Ecol. 43 (2006) 28-34.

[38] K.G.V. Smith, A Manual of Forensic Entomology, Cornell University Press, London, UK, 1986.

[39] C.G. Majka, J. Klimaszewski, J.-P. Michaud, G. Moreau, Aleochara sekanai: a significant southern and eastern range extension, Coleopterists Bull. 63 (2009) 454-455.

[40] C.G. Majka, J.-P. Michaud, G. Moreau, Adventive species of Quedius (Coleoptera: Staphylinidae) in North America: a survey and new Canadian record, in: C.G. Majka, J. Klimaszewski (Eds.), Biodiversity, Biosystematics, and Ecology of Canadian Coleoptera II, ZooKeys 22 (2009) 341-345.

[41] C.G. Majka, J.-P. Michaud, G. Moreau, A. Smetana, Philonthus hepaticus (Coleoptera: Staphylinidae) in eastern Canada: are distribution gaps distinctive features or collecting artifacts? in: C.G. Majka, J. Klimaszewski (Eds.), Biodiversity, Biosystematics, and Ecology of Canadian Coleoptera II, ZooKeys 22 (2009) 347-354.

[42] C.G. Majka, J. Klimaszewski, R.E. Lauff, New Coleoptera records from owl nests in Nova Scotia, Canada, Zootaxa 1194 (2006) 33-47. 